\title{
CAN THE RISK OF EPIDEMIC OF PREDIABETES AND DIABETES IN POLAND BE REDUCED?
}

\section{CZY MOŻNA ZMNIEJSZYĆ RYZYKO EPIDEMII STANU PRZEDCUKRZYCOWEGO I CUKRZYCY W POLSCE?}

\author{
${ }^{1}$ National Institute of Public Heath-National Institute of Hygiene Medical Centre \\ Narodowy Instytut Zdrowia Publicznego-Państwowy Zakład Higieny, Centrum Medyczne
}

\begin{abstract}
Prediabetes, i.e. impaired fasting glucose (IFG) and impaired glucose tolerance (IGT), are associated with an increased risk of developing type 2 diabetes, cardiovascular deaths, dementia, and cancer (1-4). According to the recommendations of the Polish Diabetes Association, both pre-diabetes and diabetes are indications for lifestyle modification (5). The joint efforts of many specialists in various fields may slow down this epidemic of the 21st century. The aim of the study is to answer the question "Is it possible to reduce the risk of an epidemic of prediabetes and diabetes in Poland?"
\end{abstract}

Key words: prediabetes, diabetes, risks, prevention

\section{STRESZCZENIE}

Stan przedcukrzycowy (prediabetes), czyli nieprawidłowa glikemia na czczo (IFG) oraz nieprawidłowa tolerancja glukozy (IGT) jest związany ze zwiększonym ryzykiem rozwoju cukrzycy typu 2, zgonów z przyczyn sercowonaczyniowych, demencji oraz nowotworów (1-4). Według zaleceń Polskiego Towarzystwa Diabetologicznego zarówno stan przedcukrzycowy, jak i cukrzyca są wskazaniem do modyfikacji stylu życia (5). Wspólne działania wielu specjalistów z różnych dziedzin być może wyhamują tę epidemię XXI wieku.

Celem pracy jest znalezienie odpowiedzi na pytanie „Czy można zmniejszyć ryzyko epidemii stanu przedcukrzycowego i cukrzycy w Polsce?"

Słowa kluczowe: stan przedcukrzycowy, cukrzyca, zagrożenia, zapobieganie

\section{INTRODUCTION}

Prediabetes has been shown to be not only an increased risk of developing type 2 diabetes, but also microvascular changes such as: retinopathy (6-8), and polyneuropathy, which is almost 2 times more common than in individuals with normal glucose tolerance (9). Chronic kidney disease (CKD) is more common than in individuals with normoglycemia (10). Prediabetes is also associated with an increased risk of cardiovascular disease, cardiovascular death, and all-cause death $(2,11)$. It is also associated with a higher incidence of hepatocellular carcinoma, endometrial and gastrointestinal cancers (4). According

\section{WSTĘP}

Wykazano, że stan przedcukrzycowy (prediabetes) to nie tylko zwiększone ryzyko rozwoju cukrzycy typu 2, ale także zmian mikronaczyniowych, takich jak: retinopatia (6-8), polineuropatia, która występuje prawie 2-krotnie częściej niż u osób z prawidłową tolerancją glukozy (9). Częściej występuje przewlekła choroba nerek (PChN) niż u osób z normoglikemią (10). Prediabetes wiąże się również ze zwiększonym ryzykiem chorób układu sercowo-naczyniowego, zgonów sercowo-naczyniowych i zgonów z dowolnej przyczyny $(2,11)$. Jest też związany $z$ częstszym występowaniem raka wątrobowokomórkowego, endo-

(C) National Institute of Public Health - National Institute of Hygiene / Narodowy Instytut Zdrowia Publicznego - Państwowy Zakład Higieny 
to the International Diabetes Federation (IDF), $16.3 \%$ of Poles had pre-diabetes in 2013, while it is expected to be $19.3 \%$ in 2035 (12). The report „Polska w stanie przedcukrzycowym" (Poland in a prediabetic state) shows that only $8 \%$ of respondents are aware of the risk of pre-diabetes developing into diabetes, and more than half are unable to name the symptoms of this condition or its effects on the body (13). It has been found that among individuals with prediabetes, $5-10 \%$ will develop diabetes within a year, with conversion to diabetes more likely in individuals who have impaired glucose tolerance (IGT) and impaired fasting glucose (IFG) at the same time (14). The risk of progression from prediabetes to diabetes relative to individuals with normoglycemia is more than 10 -fold higher when IGT coexists with IFG (15).

\section{THE RISK OF A DIABETIC EPIDEMIC}

Diabetes is now considered an epidemic of the $21 \mathrm{st}$ century, being the fifth cause of death, the leading cause of blindness in productive-age adults $(15,16)$, end-stage renal failure (17), lower-extremity arterial disease, leads to a 3-5 times higher risk of heart disease (18), doubles the risk of stroke (19), increases the risk of foot amputation 23-fold (20), and birth defects in newborns. It shortens life expectancy by an average of 10 years.

According to the 2019 IDF data, 463 million people have diabetes, and this number is expected to reach 578 million by 2030, and 700 million by 2045 (21). About $80-90 \%$ of all diabetics are type 2 diabetics. The increasing number of people with type 2 diabetes is associated with an increase in obesity and an ageing population $(22,23)$. In Europe, nearly 59 million adults have diabetes, and this number is expected to rise to 68 million people by 2045 (21). Additionally, $10-20 \%$ of Europeans experience a pre-diabetic state (24). There are approximately 3 million people with diabetes in Poland, of whom 700,000 are unaware of their disease (12), and 8,263 people died from this disease in 2017 (25). Poland is expected to experience a $19 \%$ increase in diabetes by 2035 (12). Therefore, in order to reduce the number of complications in patients with diabetes, it is important to incorporate a healthy lifestyle and early diagnosis.

\section{DIABETES PREVENTION AND EARLY DIAGNOSIS}

In the context of the ongoing epidemic of obesity and diabetes, screening is needed. According to the 2020 PTD guidelines, screening should be performed by fasting plasma glucose (FPG) or oral glucose metrium oraz nowotworów przewodu pokarmowego (4). Według Międzynarodowej Federacji Cukrzycy (Internatonal Diabetes Federation, IDF) w roku 2013 $16,3 \%$ Polaków miało stan przedcukrzycowy, natomiast w roku 2035 ma być 19,3\% (12). Z raportu „Polska w stanie przedcukrzycowym" wynika, że tylko $8 \%$ badanych ma świadomość zagrożenia przekształcenia się stanu przedcukrzycowego w cukrzycę, a ponad połowa nie potrafi podać objawów tego schorzenia ani jego skutków dla organizmu (13). Stwierdzono, że spośród osób z prediabetes u 5-10\% w ciągu roku rozwinie się cukrzyca, przy czym konwersja do cukrzycy częściej dotyczy osób, u których równocześnie występuje nieprawidłowa tolerancja glukozy (impaired glucose tole-rance, IGT) i nieprawidłowa glikemia na czczo (impaired fasting glucose, IFG) (14). Ryzyko progresji z prediabetes do cukrzycy w stosunku do osób z normoglikemią jest ponad 10-krotnie większe, gdy IGT współistnieje z IFG (15).

\section{ZAGROŻENIE EPIDEMIA CUKRZYCY}

Cukrzycę uważa się obecnie za epidemię XXI wieku, stanowi piątą przyczynę zgonów, jest główną przyczyną ślepoty u dorosłych w wieku produkcyjnym $(15,16)$, schyłkowej niewydolności nerek (17), miażdżycy tętnic kończyn dolnych, prowadzi do 3-5 razy wyższego ryzyka wystąpienia chorób serca (18), podwaja ryzyko udaru (19), zwiększa ryzyko amputacji stopy 23-krotnie (20) oraz wad wrodzonych u noworodków. Skraca średni oczekiwany okres życia przeciętnie o 10 lat.

Według danych IDF z 2019 roku na cukrzycę chorowało $463 \mathrm{mln}$ osób, a do $2030 \mathrm{r}$. liczba ta ma osiągnąć $578 \mathrm{mln}$, zaś do 2045 r. $700 \mathrm{mln}$ (21). Około $80-90 \%$ spośród wszystkich chorych na cukrzycę stanowią chorzy na cukrzycę typu 2. Rosnąca liczba osób z cukrzycą typu 2 wiąże się ze wzrostem występowania otyłości i starzeniem się populacji $(22,23)$. W Europie niemal 59 milionów dorosłych choruje na cukrzycę, a do roku 2045 liczba ta ma wzrosnąć do 68 milionów osób (21). Dodatkowo u 10-20\% Europejczyków występuje stan przedcukrzycowy (24). W Polsce na cukrzycę choruje ok. 3 mln osób, spośród których 700 tysięcy nie jest świadomych swojej choroby (12), a zmarło z powodu tej choroby w 2017 roku 8263 osoby (25). Według prognoz w Polsce do 2035 roku nastąpi 19-procentowy wzrost zachorowań na cukrzycę (12). Dlatego w celu zmniejszenia liczby powikłań u chorych na cukrzycę należy do leczenia zastosować zdrowy styl życia i wczesną diagnostykę. 
tolerance test (OGTT) with $75 \mathrm{~g}$ glucose to detect diabetes and pre-diabetes (5).

Indications for annual testing for carbohydrate metabolism disorders are: overweight or obesity (BMI $\geq 25 \mathrm{~kg} / \mathrm{m} 2$ or waist circumference $>80 \mathrm{~cm}$ [women], $>94 \mathrm{~cm}$ [men]), positive family history (parents, siblings), low physical activity, pre-diabetic state found in a previous study, history of gestational diabetes, birth weight $>4 \mathrm{~kg}$, hypertension $(\geq 140 / 90 \mathrm{mmHg})$, dyslipidemia (HDL $<40 \mathrm{mg} / \mathrm{dl}[<1.0 \mathrm{mmol} / \mathrm{l}]$ and/or triglycerides $>150 \mathrm{mg} / \mathrm{dl}[>1.7 \mathrm{mmol} / 1])$, polycystic ovary syndrome (PCOS), and cardiovascular disease.

When a patient reports typical symptoms of hyperglycemia, the patient's blood glucose should be measured at any time of day, regardless of the time since the last meal. If blood glucose level is $\geq 200 \mathrm{mg} /$ $\mathrm{dL}$, diabetes should be diagnosed; if it is $<200 \mathrm{mg} /$ $\mathrm{dL}$, 2-fold fasting blood glucose determination is recommended. If both tests show a value $\geq 126 \mathrm{mg} / \mathrm{dl}$, we diagnose diabetes. If the incidental blood glucose was $\geq 200 \mathrm{mg} / \mathrm{dL}$ and the patient has no symptoms of hyperglycemia, a fasting blood glucose test should be performed; if $\geq 126 \mathrm{mg} / \mathrm{dL}$, diabetes is diagnosed; if $<126 \mathrm{mg} / \mathrm{dL}$, an OGTT is performed (26).

\section{THE ROLE OF INTERNATIONAL ORGANIZATIONS IN FIGHTING DIABETES}

The World Health Organization (WHO) notes the need to create national mechanisms (multi-sectoral higher-level commissions), create conditions for leadership by ministries of health in each country, and take action to prevent overweight and obesity at an early age and in women before giving birth (27). In addition, the WHO, together with the World Economic Forum and the European Parliament, have asked governments to act decisively to prevent diabetes and chronic diseases, which have been called the "epidemic" of the 21st century (27). They recognized the importance of person-centered care and multidisciplinary work in diabetes care and called for their implementation (18). It is the role of governments to take action on health as well, ensuring that diabetics have access to technologies used to treat and control diabetes. The Polish government has taken such steps towards both obesity and diabetes control. On 14 February 2020, the Sejm passed a "Law in connection with the promotion of health-oriented consumer choices" called the "sugar tax". The introduction of this sugar tax is aimed at promoting healthy consumer behaviour, educational activities and prevention.

\section{ZAPOBIEGANIE CUKRZYCY I WCZESNA DIAGNOSTYKA}

W kontekście występującej epidemii otyłości i cukrzycy konieczne jest prowadzenie badań przesiewowych. Zgodnie z wytycznymi PTD z $2020 \mathrm{r}$ badanie przesiewowe należy przeprowadzić za pomocą oznaczania glikemii na czczo (fasting plasma glucose, FPG) lub doustnego testu tolerancji (oral glucose tolerance test, OGTT) z użyciem 75 g glukozy w celu wykrycia cukrzycy i stanu przedcukrzycowego (5).

Wskazaniami do wykonywania raz w roku badań w kierunku zaburzeń gospodarki węglowodanowej są: nadwaga lub otyłość (BMI $\geq 25 \mathrm{~kg} / \mathrm{m}^{2}$ lub obwód $\mathrm{w}$ tali $>80 \mathrm{~cm}$ [kobiety], $>94 \mathrm{~cm}$ [mężczyźni]), dodatni wywiad rodzinny (rodzice, rodzeństwo), mała aktywność fizyczna, stan przedcukrzycowy stwierdzony w poprzednim badaniu, przebyta cukrzyca ciążowa, urodzenie dziecka o masie ciała $>4 \mathrm{~kg}$, nadciśnienie tętnicze $(\geq 140 / 90 \mathrm{mmHg}$ ), dyslipidemia (HDL $<40$ $\mathrm{mg} / \mathrm{dl}[<1,0 \mathrm{mmol} / \mathrm{l}] \mathrm{i} / \mathrm{lub}$ triglicerydy $>150 \mathrm{mg} / \mathrm{dl}$ $[>1,7 \mathrm{mmol} / 1]$ ), zespół policystycznych (wielotorbielowatych) jajników (PCOS) oraz choroba układu sercowo-naczyniowego.

W sytuacji, w której pacjent zgłasza się z typowymi objawami hiperglikemii należy oznaczyć glikemię przygodną (oznaczenie wykonane o dowolnej porze dnia, bez względu na czas, jaki upłynął od ostatniego posiłku). Jeśli glikemia wynosi $\geq 200 \mathrm{mg} / \mathrm{dl}$, należy rozpoznać cukrzycę, jeśli wynosi $<200 \mathrm{mg} / \mathrm{dl}$, wskazane jest 2-krotne oznaczenie glikemii na czczo. Jeśli oba badania wykażą wartość $\geq 126 \mathrm{mg} / \mathrm{dl}$, rozpoznajemy cukrzycę. Jeśli w przygodnym oznaczeniu wartość glikemii wynosiła $\geq 200 \mathrm{mg} / \mathrm{dl}$, a pacjent nie ma objawów hiperglikemii, należy wykonać oznaczenie na czczo, jeśli $\geq 126 \mathrm{mg} / \mathrm{dl}$, rozpoznajemy cukrzycę, jeśli $<126 \mathrm{mg} / \mathrm{dl}$, wykonujemy OGTT (26).

\section{ROLA ORGANIZACJI \\ MIĘDZYNARODOWYCH W ZWALCZANIU CUKRZYCY}

Światowa Organizacja Zdrowia (World Health Organization - WHO) zwraca uwagę na potrzebę stworzenia krajowych mechanizmów (wielosektorowych komisji wyższego szczebla), tworzenia warunków do pełnienia przywódczej roli ministerstw zdrowia w każdym z krajów oraz podjęcie działań zapobiegających nadwadze i otyłości we wczesnym wieku oraz u kobiet przed porodem (27). Poza tym WHO wspólnie ze Światowym Forum Ekonomicznym i Parlamentem Europejskim zwróciły się do rządów z prośbą o zdecydowane działania, aby zapobiegać cukrzycy i chorobom przewlekłym, które nazwano „epidemią” XXI wieku (27). Uznali znaczenie opieki skoncentro- 


\section{BEHAVIORAL EDUCATION}

The incidence of type 2 diabetes is influenced by factors independent of the patient, such as ethnicity, family history, genetic factors, and factors dependent on the patient, such as obesity, physical inactivity, smoking, and poor diet, snacking between meals, and lack of meal regularity. On the other hand, a proper diet provides sufficient energy and all nutrients to maintain an individual's rate of growth and development and to maintain good health now and in the future. This indicates that nutritional goals such as ensuring proper growth and development of the body, nutritionally balanced diet, maintaining proper body weight from the earliest years of life, achieving the highest possible peak bone mass, and forming proper eating habits should be implemented from early childhood.

Overweight children are also at risk for diabetes. Errors in their diet can pose a serious health risk, as abnormalities in somatic development are strongly revealed during developmental age due to an improperly balanced diet abundant in highly processed foods, excess sugar and refined fats. The WHO alerts that by 2025 , there will be approximately 70 million children under the age of 5 with excess body weight worldwide. In Poland, the issue of overweight and obesity concerns about $10 \%$ of little children (1-3 years old), $30 \%$ of children in early school age and almost $22 \%$ of adolescents up to 15 years old (28). The incidence of obesity has tripled over the past 25 years (29), with only 1 in 3 Europeans aged 15 eating one or more portions of fresh vegetables daily (30). A very important element in the treatment of pre-diabetes and diabetes is the patient's involvement in the treatment, because $95 \%$ of the treatment effect depends on the patient's approach to the disease (27). Therapeutic patient education to encourage patient engagement in treatment should be offered to all patients with diabetes and conducted by trained diabetes staff, including a dietitian. Diet in the pre-diabetic state and in individuals with diabetes is of particular importance. Postprandial glycemia is mainly influenced by carbohydrates, the amount of which should be controlled in the whole diet and in individual meals. This relationship was demonstrated in a study published in Diabetes Care that aimed to evaluate the effect of the order of meal nutrient intake in a typical "Western" diet on postprandial glucose and insulin values in individuals with type 2 diabetes (30). Diabetics participating in the study had their fasting glucose levels measured after a 12-hour overnight break, and then consumed an isocaloric meal containing $628 \mathrm{kcal}$, including $55 \mathrm{~g}$ protein, 68 $\mathrm{g}$ carbohydrate, and $16 \mathrm{~g}$ fat. In the first week of the study, participants consumed carbohydrate source foods first, followed 15 minutes later by protein source wanej na osobie i pracy wielodyscyplinarnej w opiece diabetologicznej oraz wezwali do ich wdrożenia (18). Zadaniem rządów jest podejmowanie działań także na rzecz zdrowia, zapewnienie diabetykom dostępu do technologii stosowanych w lecznictwie i kontrolowaniu cukrzycy. Rząd Polski podjął takie działania zarówno w kierunku zwalczania otyłości, jak i cukrzycy. 14 lutego 2020 Sejm uchwalił „Ustawę w związku $\mathrm{z}$ promocją prozdrowotnych wyborów konsumentów" zwaną „podatkiem cukrowym”. Wprowadzenie tego podatku cukrowego ma na celu promocję prozdrowotnych zachowań konsumentów, działania edukacyjne i profilaktykę.

\section{EDUKACJA BEHAWIORALNA}

$\mathrm{Na}$ występowanie cukrzycy typu 2 mają wpływ czynniki niezależne od chorego, takie jak: pochodzenie etniczne, historia rodzinna, czynniki genetyczne oraz czynniki zależne od chorego, takie jak: otyłość, brak aktywności fizycznej, palenie papierosów oraz nieprawidłowy sposób żywienia, podjadanie między posiłkami, brak regularności posiłków. Natomiast prawidłowy sposób żywienia to taki, który zapewnia dostarczenie energii i wszystkich składników odżywczych w ilościach wystarczających do utrzymania osobniczego tempa wzrostu i rozwoju organizmu oraz warunkuje dobry stan zdrowia, aktualnie i w przyszłości. To wskazuje, że już od wczesnego dzieciństwa należy realizować cele żywieniowe, takie jak: zapewnienie prawidłowej dynamiki wzrostu i rozwoju organizmu, żywienie zbilansowane pod względem wartości odżywczej, utrzymanie należnej masy ciała od najwcześniejszych lat życia, osiągniecie jak najwyższej szczytowej masy kostnej, kształtowanie prawidłowych nawyków żywieniowych.

W grupie ryzyka zachorowania na cukrzycę są także dzieci z nadwagą. Błędy w ich sposobie żywienia mogą stanowić poważne zagrożenie zdrowia, gdyż $\mathrm{w}$ wieku rozwojowym silnie ujawniają się nieprawidłowości w rozwoju somatycznym spowodowane niewłaściwie zbilansowaną dietą obfitującą $\mathrm{w}$ wysoko przetworzone pożywienie, nadmiar cukru i rafinowanych tłuszczów. WHO alarmuje, że do 2025 roku na świecie będzie ok. $70 \mathrm{mln}$ dzieci do 5 roku życia z nadmierna masą ciała. W Polsce problem nadwagi i otyłości dotyczy około 10\% małych dzieci (1-3 lata), $30 \%$ dzieci w wieku wczesnoszkolnym i niemal $22 \%$ młodzieży do 15 roku życia (28). Występowanie otyłości potroiło się w ciągu ostatnich 25 lat (29), tylko 1 na 3 Europejczyków w wieku 15 lat spożywa codziennie jedną lub więcej porcji świeżych warzyw (30). Bardzo ważnym elementem w leczeniu stanu przedcukrzycowego i cukrzycy jest zaangażowanie się pacjenta w leczenie, bowiem 95\% efektów leczenia zależy od 
foods and vegetables and fats. In the second week, the order of eating nutrients was reversed. It was found that if vegetables and proteins were consumed before carbohydrates, patients' glucose levels were $29 \%, 37 \%$ and $17 \%$ lower at 30,60 and 120 minutes after the meal. In addition, lower postprandial insulin concentrations were found when participants ate vegetables and protein first. The authors suggest that this meal pattern may improve insulin sensitivity.

The effectiveness of behavioral therapy in diabetes prevention has also been demonstrated in the Finnish Diabetes Prevention Study (FDPS) (31). Study participants (individuals aged 40-65 years with BMI $\geq 25 \mathrm{~kg} / \mathrm{m} 2$ and IGT - glucose at $120 \mathrm{~min}: 140-200$ $\mathrm{mg} / \mathrm{dl}$ ) were randomly assigned to the intervention and control groups. The control group received general information on diet and physical activity, and the intervention group received individualized recommendations so as to achieve 5 goals: weight reduction of at least $5 \%$, reduction of energy from fat to $30 \%$, from saturated fat to $10 \%$, fiber intake of at least $15 \mathrm{~g}$ per $1000 \mathrm{kcal}$, and increasing physical activity to at least 30 minutes per day. The mean follow-up period was 3.2 years. The behavioral intervention was associated with a $58 \%$ reduction in the risk of developing diabetes. In addition, no one in the study developed diabetes if a minimum of 4 of the 5 goals were achieved. Lifestyle changes were also associated with improvements in lipid profile and reductions in blood pressure. In contrast, those who failed to achieve lifestyle changes faced a near 35\% risk of developing diabetes (32).

Also noteworthy are the Diabetes Prevention Program (DPP) study (33), which aimed to test whether a behavioral intervention or the use of metformin is effective in preventing or delaying the onset of diabetes in people with prediabetes, and the study (RCT) with the acronym D-CLIP (The Diabetes Community Lifestyle Improvement Program), which aimed to evaluate the effectiveness of expert recommendations for the incremental prevention of diabetes: lifestyle modification and, when indicated, the use of metformin among people with prediabetes (34). The DPP study confirmed previous observations of a $58 \%$ reduction in the risk of developing type 2 diabetes after implementing behavioral intervention.

The RCT involved the study of 578 adults with isolated impaired fasting glucose (isolated IFG - iIFG), isolated impaired glucose tolerance (isolated IGT iIGT), or with coexistent IFG and IGT, with associated overweight or obesity (with Asian-specific BMI (Body Mass Index) cut-off values: BMI between 23 and $<27.5$ $\mathrm{kg} / \mathrm{m}^{2}$ for overweight, BMI $\geq 27.5 \mathrm{~kg} / \mathrm{m}^{2}$ for obesity, and/ or waist circumference $\geq 90 \mathrm{~cm}$ for men or $\geq 80 \mathrm{~cm}$ for women). Subjects were randomly assigned to a group jego podejścia do choroby (27). Edukacja terapeutyczna pacjenta w celu zachęcenia go do zaangażowania się w leczenie powinna być proponowana wszystkim pacjentom z cukrzycą i prowadzona przez wyszkolony personel diabetologiczny, w tym przez dietetyka. Dieta w stanie przedcukrzycowym i u osób chorujących na cukrzycę ma szczególne znaczenie. $\mathrm{Na}$ wartość glikemii poposiłkowej największy wpływ wywierają węglowodany, których ilość powinna być kontrolowana w całej diecie i w poszczególnych posiłkach. Zależność tę wykazano w badaniu opublikowanym w Diabetes Care, którego celem była ocena wpływu kolejności spożycia składników odżywczych w posiłku w typowej ,zachodniej” diecie na poposiłkowe wartości glukozy i insuliny u osób chorych na cukrzycę typu 2 (30). Diabetykom uczestniczącym w badaniu oznaczono stężenie glukozy na czczo po 12-godzinnej przerwie nocnej, a następnie spożywali oni izokaloryczny posiłek zawierający $628 \mathrm{kcal}$, w tym $55 \mathrm{~g}$ białka, $68 \mathrm{~g}$ węglowodanów i $16 \mathrm{~g}$ tłuszczu. W pierwszym tygodniu badania uczestnicy spożywali jako pierwsze produkty będące źródłem węglowodanów, 15 minut później - produkty będące źródłem białka oraz warzywa i tłuszcze. W drugim tygodniu kolejność jedzenia składników odżywczych była odwrócona. Stwierdzono, że jeśli warzywa i białka były spożywane przed węglowodanami, stężenie glukozy u pacjentów było o $29 \%$, 37\% i $17 \%$ mniejsze w 30 ., 60. i 120 minucie po posiłku. Ponadto stwierdzono mniejsze poposiłkowe stężenia insuliny, gdy uczestnicy jedli w pierwszej kolejności warzywa i białka. Autorzy sugerują, że taki wzór posiłku może poprawić wrażliwość na insulinę.

Skuteczność terapii behawioralnej w prewencji cukrzycy wykazano także w badaniu Finnish Diabetes Prevention Study (FDPS) (31). Uczestnicy badania (osoby w wieku $40-65$ lat $\mathrm{z}$ BMI $\geq 25 \mathrm{~kg} / \mathrm{m}^{2}$ i IGT glukoza w $120 \mathrm{~min}$ : 140-200 mg/dl) zostali losowo przydzieleni do grupy interwencyjnej i kontrolnej. Grupa kontrolna otrzymywała ogólne informacje dotyczące diety i aktywności fizycznej, a grupa interwencyjna otrzymywała indywidualne zalecenia tak, aby osiągnąć 5 celów: redukcję masy ciała minimum $5 \%$, ograniczenie energii pochodzącej z tłuszczów do $30 \%$, z tłuszczów nasyconych do $10 \%$, spożycie błonnika minimum $15 \mathrm{~g}$ na $1000 \mathrm{kcal}$ oraz zwiększenie aktywności fizycznej do minimum 30 minut dziennie. Średni okres obserwacji wynosił 3,2 roku. Interwencja behawioralna wiązała się z 58\% redukcją ryzyka rozwoju cukrzycy. Poza tym u nikogo spośród uczestników badania nie rozwinęła się cukrzyca, jeśli osiągnięto minimum 4 z 5 celów. Zmiana stylu życia wiązała się także z poprawą profilu lipidowego oraz redukcją ciśnienia tętniczego. Natomiast u osób, u których nie udało się osiągnąć zmiany stylu życia, ryzyko rozwoju cukrzycy było bliskie $35 \%$ (32). 
undergoing healthy lifestyle counseling (control group) or to a group undergoing a 6-month lifestyle modification program based on guidelines consistent with the U.S. Diabetes Prevention Program (DPP). Participants were trained to improve diet quality and reduce food intake by keeping food diaries, reducing portion sizes, and increasing intake of fiber-rich foods, among other things. They were supervised by fitness instructors, personal health coaches and volunteers. After 3 years, there was a relative risk reduction (RRR) of $32 \%(95 \%$ CI $7-50)$ in treated subjects compared with control subjects. Diabetes developed after 3 years in $34.9 \%$ of control subjects and $25.7 \%$ of treated subjects; the mean annual incidence was $11.1 \%$ and $7.8 \%$, respectively $(\mathrm{p}=0.014)$. The number needed to treat (NNT) to prevent one case of diabetes was 9.8 (95\% CI 5.4-53.9). The RRR varied according to the type of carbohydrate disorder: for IFG accompanied by IGT the result was significant at 36\% (95\% CI 3-57), whereas for iIGT it was $31 \%(95 \%$ CI $-31,64)$ and for iIFG it was $12 \%(95 \%$ CI $-80,57)$. The reduction in incidence was found to be greater in individuals over 50 years of age, in men, and in obese participants. During the 6-month program, improvements were observed in energy, carbohydrate, and fat intake ( $p<0.001$ for each category), whereas the decrease was not significant in the control group. It has been shown that it is possible to reduce the risk of developing diabetes within 3 years by $58 \%$ if subjects reduce excess body weight by $7 \%$ and incorporate physical activity for a minimum of 150 minutes per week.

\section{RECOMMENDATIONS OF THE DIABETES POLAND (POLSKIE TOWARZYSTWO DIABETOLOGICZNE, PTD) AND EUROPEAN ASSOCIATION FOR THE STUDY OF DIABETES}

According to the recommendations of the Diabetes Poland (Polskie Towarzystwo Diabetologiczne, PTD) And European Association For The Study Of Diabetes, pre-diabetic state is an indication for lifestyle modification (5).

The report "Poland in a pre-diabetic state" shows that $74 \%$ of respondents do not eat breakfast at home, $47 \%$ eat sweets at least twice a week, and $24 \%$ eat highly processed foods (13). Therefore, according to experts, pre-diabetic patients should be given recommendations for a healthy lifestyle, i.e. weight reduction and maintenance and introduction of physical activity min. 150 min. per week. Diabetes experts highlight the importance of repeated advice on lifestyle changes in effective diabetes prevention and education by qualified individuals. In their opinion, in the treatment of diabetes, there is no universal diet for
Na uwagę zasługują także badania Diabetes Prevention Program (DPP) (33), którego celem było sprawdzenie, czy interwencja behawioralna lub zastosowanie metforminy są skuteczne w zapobieganiu lub opóźnianiu wystąpienia cukrzycy u osób z prediabetes oraz badanie (RCT) o akronimie D-CLIP (The Diabetes Community Lifestyle Improvement Program), którego celem była ocena skuteczności zaleceń ekspertów dotyczących stopniowej prewencji cukrzycy: modyfikacji stylu życia oraz, gdy istnieją ku temu wskazania stosowania metforminy wśród osób ze stanem przedcukrzycowym (34). Badanie DPP potwierdziło wcześniejsze obserwacje $58 \%$ redukcji ryzyka rozwoju cukrzycy typu 2 po wdrożeniu postępowania behawioralnego.

W badaniu RCT przebadano 578 osób dorosłych z izolowaną nieprawidłową glikemią na czczo (isolated IFG - iIFG), izolowaną nieprawidłową tolerancją glukozy (isolated IGT - iIGT) lub ze współistniejącymi IFG i IGT, z towarzyszącą nadwagą lub otyłością (ze specyficznymi dla Azji punktami odcięcia wskaźnika masy ciała BMI (Body Mass Index): BMI od 23 do $<27,5 \mathrm{~kg} / \mathrm{m}^{2}$ dla nadwagi, BMI $\geq 27,5 \mathrm{~kg} / \mathrm{m} 2$ dla otyłości i/lub obwód w pasie $\geq 90 \mathrm{~cm}$ w przypadku mężczyzn lub $\geq 80 \mathrm{~cm} w$ przypadku kobiet). Badani byli przydzielani losowo do grupy poddanej poradnictwu na temat zdrowego stylu życia (grupa kontrolna) lub do grupy objętej 6-miesięcznym programem modyfikacji stylu życia opartym na założeniach zgodnych z U.S. Diabetes Prevention Program (DPP). Uczestnicy byli szkoleni m.in. w zakresie poprawy jakości diety i redukcji ilości spożywanych pokarmów poprzez prowadzenie dzienników odżywiania, zmniejszenie wielkości porcji, zwiększenie spożycia pokarmów bogatych w błonnik. Otoczeni byli opieką instruktorów fitness, personalnych trenerów zdrowia oraz wolontariuszy. Po 3 latach stwierdzono względne zmniejszenie ryzyka wystąpienia cukrzycy (relative risk reduction - RRR) u uczestników poddanych interwencji w porównaniu z osobami z grupy kontrolnej o $32 \%$ (95\% CI 7-50). Cukrzyca rozwinęła się po 3 latach u 34,9\% osób z grupy kontrolnej i u $25,7 \%$ osób poddanych interwencji, średnia roczna zapadalność wyniosła odpowiednio $11,1 \%$ i 7,8\% (p = 0,014). Liczba osób, których trzeba poddać interwencji, aby zapobiec jednemu przypadkowi wystąpienia cukrzycy (numer needed to treat - NNT), wyniosła 9,8 ( $95 \%$ CI 5,4-53,9). RRR było różne w zależności od rodzaju zaburzeń gospodarki węglowodanowej: dla IFG z towarzyszącym IGT wynik był istotny i wyniósł $36 \%$ (95\% CI 3-57), z kolei dla iIGT wyniósł $31 \%$ (95\% CI $-31,64)$, a dla iIFG $12 \%(95 \%$ CI -80, 57). Redukcja zapadalności okazała się większa u osób powyżej 50. roku życia, u mężczyzn oraz u otyłych uczestników. Podczas trwania 6-miesięcznego programu zaobserwowano poprawę w zakresie spożycia energii, węglowodanów oraz 
all patients with diabetes, dietary recommendations should be individualized according to the needs and abilities of the patient. The optimal macronutrient ratio for a patient should be determined individually, taking into account age, physical activity, presence of diabetic complications, and additional conditions. In contrast, the intake of simple carbohydrates should be minimized. The daily intake of fructose should not exceed $50 \mathrm{~g}$, and the minimum dietary fiber supply should be $25 \mathrm{~g}$ or $15 \mathrm{~g}$ per 1,000 kcal of diet (5).

The 2020 PTD recommendations emphasize the importance of limiting carbohydrate supply not only in the whole diet but also in individual meals, and a daily calorie deficit of 500-750 kcal is considered safe (5).

\section{THE ROLE OF FOOD MANUFACTURERS IN CHRONIC DISEASE PREVENTION}

Health care systems cannot meet the challenge of preventing chronic diseases, including diabetes, on their own. Therefore, the European Commission has set up a High Level Group European Union (HLGEU) on Nutrition and Physical Activity, consisting of representatives of the EU governments and the European Free Trade Association (EFTA). The HLG-EU works on priorities such as improving food formulations, reducing children's exposure to marketing of foods high in fat, salt and sugars, labeling and food procurement. It also improves contact between governments and the EU Platform for Action on Diet, Physical Activity and Health so that appropriate collaboration with and between stakeholders can take place. In addition, it facilitates the sharing of evidence, data, and best practices for policymakers, identifies gaps in research and supports health in all policies, and works to reduce health inequities. The HLG-EU may also be requested by the Commission to prepare appropriate prevention and promotion initiatives agreed by the Steering Group on Health Promotion, Disease Prevention. Its goal now is to reduce fat and sugar content by at least $10 \%$ by the end of 2020. Therefore, most food manufacturers have embraced reformulation and recognized the need for interdisciplinary collaboration to influence market products. It has been shown that type 2 diabetes can be virtually prevented in individuals prepared to make very significant behavioral changes in five areas: healthy body weight, physical activity, fibre, fat and saturated fat intake $(35,36)$.

Entrepreneurs can become exemplary providers of healthy workplaces. A healthy staff and access to healthy lifestyle choices has significant economic and productivity benefits. tłuszczów ( $\mathrm{p}<0,001$ dla każdej kategorii), podczas gdy $\mathrm{w}$ grupie kontrolnej spadek ten był nieistotny. Wykazano, że możliwa jest redukcja ryzyka rozwoju cukrzycy w ciągu 3 lat o 58\%, jeśli badani zredukują nadmierną masę ciała o 7\% i wprowadzą wysiłek fizyczny przez minimum 150 minut tygodniowo.

\section{ZALECENIA POLSKIEGO I EUROPEJSKIEGO TOWARZYSTWA DIABETOLOGICZNEGO}

Według zaleceń Polskiego i Europejskiego Towarzystwa Diabetologicznego stan przedcukrzycowy jest wskazaniem do modyfikacji stylu życia (5).

Z raportu „Polska w stanie przedcukrzycowym” wynika, że $74 \%$ ankietowanych nie spożywa śniadania w domu, $47 \%$ zjada co najmniej dwa razy w tygodniu słodycze, a 24\% żywność wysokoprzetworzoną (13). Dlatego zdaniem ekspertów pacjenci w stanie przedcukrzycowym powinni otrzymywać zalecenia na temat zdrowego stylu życia, tj. redukcji masy ciała i jej utrzymania oraz wprowadzeniu aktywności fizycznej min. 150 min. na tydzień. Eksperci w dziedzinie diabetologii podkreślają znaczenie powtarzalności porad dotyczących zmian stylu życia w skutecznej prewencji cukrzycy oraz edukacji przez osoby do tego uprawnione. Ich zdaniem w leczeniu cukrzycy nie ma diety uniwersalnej dla wszystkich pacjentów z cukrzycą, zalecenia dietetyczne powinny być indywidualizowane w zależności od potrzeb i możliwości pacjenta. Optymalne dla chorego proporcje makroskładników powinny być ustalane indywidualnie z uwzględnieniem wieku, aktywności fizycznej, obecności powikłań cukrzycy, schorzeń dodatkowych. Natomiast spożycie węglowodanów prostych należy ograniczyć do minimum. Dzienne spożycie fruktozy nie powinno przekraczać $50 \mathrm{~g}$, a minimalna podaż błonnika pokarmowego powinna wynosić $25 \mathrm{~g}$ lub $15 \mathrm{~g}$ na $1000 \mathrm{kcal}$ diety (5).

W zaleceniach PTD z 2020 r podkreśla się znaczenie ograniczania podaży węglowodanów nie tylko w całej diecie ale także w poszczególnych posiłkach, a dzienny deficyt kaloryczny wynoszący $500-750 \mathrm{kcal}$ uważa się za bezpieczny (5).

\section{ROLA PRODUCENTÓW ŻYWNOŚCI W PROFILAKTYCE CHORÓB PRZEWLEKŁYCH}

Systemy opieki zdrowotnej nie mogą samodzielnie sprostać wyzwaniu profilaktyki chorób przewlekłych, w tym cukrzycy. Dlatego Komisja Europejska powołała Grupę wysokiego szczebla ds. Odżywiania i aktywności fizycznej HLG-UE (High Level Group European Union) składającą się z przedstawicieli rządów UE i Europejskiego Stowarzyszenia Wolnego Handlu 


\section{SUMMARY}

With the growing epidemic of obesity and type 2 diabetes, every effort should be made to prevent the development of type 2 diabetes. There is a need for widespread screening to detect carbohydrate disorders at an early stage. Promotion of a healthy lifestyle, physical activity, proper diet, and weight reduction can significantly reduce the risk of developing type 2 diabetes, even in people with pre-diabetes (37). Importantly, behavioral therapy aimed at reducing the risk of type 2 diabetes is the same as prevention of other cardiovascular disease risk factors.

The pre-diabetic state poses a challenge not only to the physician and patient, but also to the food industry. The fight against obesity and diabetes are causing more and more food manufacturers to decide to reformulate their products, specifically to reduce sugar, salt and fat.

\section{REFERENCES}

1. WHO. Definition and Diagnosis of Diabetes Mellitus and Intermediate Hyperglycemia. Geneva: World Health Organization; 2006; pp. 1-46. Report of a WHO/IDF Consultation.

2. Huang Y, Cai X, Chen $P$, et al. Associations of prediabetes with all-cause and cardiovascular mortality: a meta-analysis. Ann. Med. 2014 Dec;46(8):684-92. DOI: 10.3109/07853890.2014.955051.

3. Pal K, Mukadam N, Petersen I, et al. Mild cognitive impairment and progression to dementia in people with diabetes, prediabetes and metabolic syndrome: a systematic review and meta-analysis. Soc Psychiatry Psychiatr Epidemiol 2018 Nov;53(11):1149-1160.

4. Huang Y, Cai X, Qiu M, et al. Prediabetes and the risk of cancer: a meta-analysis. Diabetologia 2014 Nov;57(11):2261-2269. DOI: 10.1007/s00125-0143361-2.

5. Guidelines on the management of diabetic patients. A position of Diabetes Poland. Clin Diabetol 2020; 9,1.

6. Lamparter J, Raum P, Pfeiffer N, et al. Prevalence and associations of diabetic retinopathy in a large cohort of prediabetic subjects: the Gutenberg Health Study. J. Diabetes Complications 2014 Jul-Aug;28(4):482-487. DOI: 10.1016/j. jdiacomp.2014.02.008.

7. Tapp RJ, Tikellis G, Wong TY, et al. Longitudinal association of glucose metabolism with retinopathy: results from the Australian Diabetes Obesity and Lifestyle (AusDiab) study. Diabetes Care 2008 Jul;31(7):1349-1354. DOI: 10.2337/dc07-1707.
(European Free Trade Association - EFTA). HLG-UE pracuje nad priorytetami, takimi jak: ulepszenie receptur produktów spożywczych, zmniejszenie narażenia dzieci na marketing żywności bogatej w tłuszcz, sól i cukry, etykietowanie i zamówienia publiczne na żywność. Poprawia też kontakt między rządami a platformą UE na rzecz działań w zakresie diety, aktywności fizycznej i zdrowia, tak aby mogła mieć miejsce odpowiednia współpraca z zainteresowanymi stronami i między nimi. Poza tym ułatwia wymianę dowodów, danych i najlepszych praktyk dla decydentów, identyfikuje luki w badaniach i wspiera zdrowie we wszystkich politykach oraz działa na rzecz zmniejszania nierówności zdrowotnych. HLG-UE może również zostać poproszona przez Komisję o przygotowanie odpowiednich inicjatyw prewencyjnych i promocyjnych uzgodnionych przez grupę sterującą ds. Promocji i zapobiegania. Jej celem jest obecnie obniżenie zawartości tłuszczu i cukru o co najmniej 10\% do końca 2020 roku. Dlatego większość producentów żywności podjęła działania reformulacyjne i dostrzegła konieczność interdyscyplinarnej współpracy w zakresie wpływu na produkty rynkowe. Wykazano, że można praktycznie zapobiec wystąpieniu cukrzycy typu 2 u osób przygotowanych do wprowadzenia bardzo istotnych zmian behawioralnych $\mathrm{w}$ zakresie pięciu obszarów: zdrowej masy ciała, aktywności fizycznej, spożycia błonnika, tłuszczów i tłuszczów nasyconych $(35,36)$.

Przedsiębiorcy mogą stać się przykładowymi podmiotami zapewniającymi zdrowe miejsca pracy. Zdrowy personel i dostęp do zdrowych wyborów w zakresie stylu życia przynosi istotne korzyści gospodarcze i dotyczące produktywności.

\section{PODSUMOWANIE}

W obliczu narastającej epidemii otyłości i cukrzycy typu 2 należy dołożyć wszelkich starań, aby zapobiec rozwojowi cukrzycy typu 2. Konieczne jest prowadzenie powszechnych badań przesiewowych w celu wykrycia zaburzeń gospodarki węglowodanowej na wczesnym etapie. Promocja zdrowego stylu życia, aktywność fizyczna, odpowiednia dieta, redukcja masy ciała pozwalają na znaczne zmniejszenie ryzyka rozwoju cukrzycy typu 2, także u osób ze stwierdzonym stanem przedcukrzycowym (37). Co istotne, terapia behawioralna ukierunkowana na redukcję ryzyka cukrzycy typu 2 jest tożsama z profilaktyką innych czynników ryzyka chorób sercowo-naczyniowych.

Stan przedcukrzycowy stanowi wyzwanie nie tylko dla lekarza i pacjenta, ale także przemysłu spożywczego. Walka z otyłością i cukrzycą sprawiają, że coraz więcej producentów produktów spożywczych decyduje się na zmianę składu swoich produktów, a dokładnie na obniżenie zawartości cukru, soli i tłuszczu. 
8. Singleton JR, Smith AG, Russell JW., et al. Microvascular complications of impaired glucose tolerance. Diabetes 2003 Dec;52(12):2867-2873.

9. Ziegler D, Rathmann W, Dickhaus $T$, et al. Prevalence of polyneuropathy in pre-diabetes and diabetes is associated with abdominal obesity and macroangiopathy: the MONICA/KORA Augsburg Surveys S2 and S3. Diabetes Care 2008 Mar;31(3):464-469.

10. Plantinga LC, Crews DC, Coresh J, et al. Prevalence of chronic kidney disease in US adults with undiagnosed diabetes or prediabetes. Clin. J. Am. Soc. Nephrol. 2010 Apr;5(4):673-682. DOI: 10.2215/CJN.07891109

11. Huang Y, Cai X, Mai W, et al. Association between prediabetes and risk of cardiovascular disease and all cause mortality: systematic review and meta-analysis. BMJ 2016 Nov23;355:i5953. DOI: 10.1136/bmj.i5953

12. International Diabetes Federation. IDF Diabetes Atlas 6th Edition. 2013

13. Strojek K. Raport „Polska w stanie przedcukrzycowym". Warszawa, październik 2016.

14. Tabák AG, Herder C, Rathmann W, et al. Prediabetes: A high-risk state for developing diabetes. Lancet 2012;379(9833):2279-2290. DOI:10.1016/S0140-6736(12)60283-9.

15. Centers for Disease Control and Prevention. National diabetes fact sheet: national estimates and general information on diabetes and prediabetes in the United States, 2011. Atlanta, GA: U.S. Department of Health and Human Services, Centers for Disease Control and Prevention, 2011. http://www.diabetesincontrol.com/wp-content/ uploads/PDF/ndep_diabetes_facts_2011.pdf

16. Arun CS, Ngugi N, Lovelock L, Taylor R. Effectiveness of screening in preventing blindness due to diabetic retinopathy. Diabet Med 2003; 20(3):186-190.

17. Department of Health. Improving Diabetes Services: The NSF Four Years OnThe Way Ahead: The Local Challenge Report from Dr Sue Roberts National Clinical Director for Diabetes, for the Secretary of State for Health. 2007;43-45. http://data.parliament.uk/DepositedPapers/Files/ DEP2007-0182/DEP2007-0182.pdf

18. Ryden L, Standl, E, Bartnik M, et al. Guidelines on diabetes, pre-diabetes, and cardiovascular diseases: executive summary. The Task Force on Diabetes and Cardiovascular Diseases of the European Society of Cardiology (ESC) and of the European Association for the Study of Diabetes (EASD). European Heart Journal 2007;28,88136. doi:10.1093/eurheartj/ehl2602007; https:// www.escardio.org/static-file/Escardio/Guidelines/ publications/DIABETguidelines-diabetes-ES.pdf
19. Jeerakathil T, Johnson JA, Simpson SH et al. Short-term risk of stroke is doubled in persons with newly treated type 2 diabetes compared with persons without diabetes: a population based cohort study. Stroke 2007; 38(6): 1739-43.

20. NHS Diabetes. Factsheet no. 37. Foot care for people with diabetes in the NHS in England: The economic case for change. 2012.

21. Saeedi P, Petersohn I, Salpea P, et al. Global and regional diabetes prevalence estimates for 2019 and projections for 2030 and 2045: Results from the International Diabetes Federation Diabetes Atlas, 9th edition. Diabetes Res Clin Pract 2019; 157:107843,1-10. DOI:10.1016/j. diabres.2019.107843

22. Diabetes In Europe - Policy Puzzle. The state we are in. IDF Europe, FEND, PCDE and EURADIA 2014;8-164.

23. Tatoń J. patofizjologiczna charakterystyka zaburzeń sercowo-naczyniowych powodowanych nadwagą i otyłością. Medycyna Metaboliczna, 2015; 2, , tom XIX, 91-116.

24. The DECODE Study Group. Age- and sex-specific prevalences of diabetes and impaired glucose regulation in 13 European cohorts. Diabetes Care 2003; 26(1): 61-69.

25. Roczniki GUS 2019

26. Guidelines on the management of diabetic patients. A position of Diabetes Poland. Clin. Diabet. 2018; 7, 1-90. DOI: 10.5603/DK.2018.0001

27. Health 2020. A European policy framework and strategy for the 21st century (2013). WHO Regional Office for Europe.

28. https://www.euro.who.int/_data/assets/pdf_ file/0011/199532/Health2020-Long.pdf

29. https://ncez.pl/abc-zywienia-/zasady-zdrowegozywienia/nadwaga-i-otylosc-wsrod-dzieci-imlodziezy-

30. Mladovsky P, Allin S, Masseria C et al. Health in the European Union. Trends and analysis. World Health Organization 2009, on behalf of the European Observatory on Health Systems and Policies. 2009. https://apps.who.int/iris/bitstream/ handle/10665/327971/9789289041904-eng.pdf

31. Shukla AP, Iliescu RG, Thomas C, et al. Food order has a significant impact on postprandial glucose and insulin levels. Diabetes Care 2015;38:e98-e99.

32. Lindstrom J, Ilanne-Parikka P, Peltonen M, et al. Sustained reduction in the incidence of type 2 diabetes by lifestyle intervention: follow-up of the Finnish Diabetes Prevention Study. Lancet 2006;368:1673-1679.

33. Laaksonen DE, Lindstrom J, Tuomilehto J, et al. Increased physical activity is a cornerstone in the prevention of type 2 diabetes in high-risk individuals. Diabetologia 2007;50:2607-2608. 
34. Knowler WC, Fowler SC, Hamman RF, et al. 10year follow-up of diabetes incidence and weight lossin the Diabetes Prevention Program Outcomes Study. Lancet 2009;374:1677-1686.

35. Weber MB, Ranjani H, Staimez LR et al. The Stepwise Approach to Diabetes Prevention: Results From the D-CLIP Randomized Controlled Trial. Diabetes Care 2016;39:1760-1767.

36. Lindstrom J, Ilanne-Parikka P, Peltonen M, et al. Sustained reduction in the incidence of type 2 diabetes by lifestyle intervention: follow-up of the Finnish Diabetes Prevention Study. Lancet 2006;368:1673-1679.

37. Simmons RK, Harding AH, Jakes RW, et al. How much might achievement of diabetes prevention behaviour goals reduce the incidence of diabetes if implemented at the population level? Diabetologia 2006;49:905-911.
38. Pachocka L.: Otyłość i cukrzyca - wadliwe żywienie główną przyczyną ich powstawania. Nowa Medycyna 1998;21-22:15 - 22.

Received: 5.01.2021

Accepted for publication: 12.02.2021

Otrzymano: 5.01.2021 r.

Zaakceptowano do publikacji: $12.02 .2021 \mathrm{r}$.

Address for correspondence:

Adres do korespondencji:

Lucyna M Pachocka

Centrum Medyczne,

Narodowy Instytut Zdrowia Publicznego

- Państwowy Zakład Higieny,

ul. Chocimska 24, 00-791 Warszawa

email:1pachocka@pzh.gov.pl 